\title{
ANALISIS KANDUNGAN FOSFOR MENGGUNAKAN SPECTROFOTOMETER UV- VIS PADA KACANG HIJAU YANG DIAMBIL DARI PASAR KOTA PEKANBARU
}

\author{
Pangoloan Soleman Ritonga, Sukindro \\ Jurusan Pendidikan Kimia, Fakultas Tarbiyah dan Keguruan UIN SUSKA Riau \\ Solemanriau@yahoo.co.id
}

\begin{abstract}
Analysis of phosphorus content in green beans was done. Sampling was conducted with a random method (random) from 3 different markets namely the market of Panam, the market of Arengka and the market of Giant. This study aims to analyze the levels of phosphorus in the green beans in the markets of Pekanbaru. The method used in this study is the UV-Vis spectrophotometer, which measured at a wavelength of $400 \mathrm{~nm}$. Research was conducted at the Laboratory of Pathology, Entomology and Microbiology (PEM) Faculty of Agricultural and animal husbandry Pekanbaru Riau Suska UIN 2010. Based on the results obtained from 3 samples of green beans that were analyzed, the results showed that phosphorus levels in green beans from the market of Arengka is $82.3 \mathrm{mg} / 10 \mathrm{~g}$, from Panam Market is $\mathrm{mg} / 10 \mathrm{~g} 88.05$ and market of Giant is $89.63 \mathrm{mg} / 10 \mathrm{~g}$. From 3 different markets that phosphorus levels obtained ranged from 82.3 to $89.63 \mathrm{mg} / 10 \mathrm{gr}$.
\end{abstract}

Keywords: Phosphor, Green beans, Spectrophotometry, UV-Vis

\section{PENDAHULUAN}

Menurut Soeprapto, tanaman kacang hijau merupakan salah satu jenis tanaman kacangkacangan yang tergolong pada tanaman semusim yang berumur pendek yaitu \pm 60 hari. Tanaman kacang hijau berbatang tegak dengan ketinggian sangat bervariasi, antara 30-60 cm, tergantung varietasnya. Cabangnya menyamping, batang utama berbentuk bulat dan berbulu, warna batang ada yang hijau dan ada yang ungu. Daunnya trifoliate (terdiri dari tiga helaian) dan letaknya berseling. Tangkai daunnya cukup panjang, lebih panjang dari daunnya. Warna daunnya hijau muda sampai hijau tua. Tanaman kacang hijau termasuk berbunga sempurna, bunga berbentuk kupu-kupu berwarna kuning. Bunga tersusun dalam tandan, keluar pada cabang serta batang dan dapat menyerbuk sendiri (Syam Suardi, 2005; 4).

Kacang hijau (Phaseolus Radiatus) yang juga disebut Mungbean merupakan tanaman yang dapat tumbuh hampir di semua tempat di Indonesia. Berbagai jenis makanan (olahan) asal kacang hijau seperti bubur kacang hijau, minuman kacang hijau, kue/panganan tradisional dan kecambah kacang hijau telah sejak lama dikenal oleh masyarakat Indonesia.

Meskipun tanaman kacang hijau memiliki banyak manfaat, namun tanaman ini masih kurang mendapatkan perhatian petani

untuk dibudidayakan. Padahal, tanaman kacang hijau memiliki potensi yang tinggi untuk dikembangkan. Dibanding dengan tanaman kacang-kacangan lainnya, kacang hijau memiliki kelebihan ditinjau dari segi agronomi dan ekonomis, seperti: (a) lebih tahan kekeringan; (b) serangan hama dan penyakit lebih sedikit; (c) dapat dipanen pada umur 55-60 hari; (d) dapat ditanam pada tanah yang kurang subur; dan (e) cara budidayanya mudah (Atman, 2007; 1).

Kacang hijau mengandung kalsium (124 $\mathrm{mg} / 100 \mathrm{~g}$ ) dan fosfor $(326 \mathrm{mg} / 100 \mathrm{~g}$ ) yang relatif tinggi. Ini berarti kacang hijau bermanfaat untuk memperkuat kerangka tulang yang sebagian besar tersusun dari kalsium dan fosfor (Ali Khomsan, 2006; 11-12).

Dari data statistik (BKP Propinsi Riau) diperoleh kebutuhan masyarakat Pekanbaru dalam mengkonsumsi kacang hijau adalah 1,04 $\mathrm{kg} / \mathrm{tahun} /$ kota/orang. Ini menunjukkan bahwa 
tingkat konsumsi masyarakat pekanbaru terhadap kacang hijau adalah tinggi. Di Pekanbaru tersedia konsumsi 7 ton/tahun dari kebutuhan kacang hijau/tahun 816,80 ton/tahun. Jadi di kota Pekanbaru mengalami kekurangan -810 ton/tahun sehingga untuk mencukupi kebutuhan tersebut Badan Katahanan Pangan Propinsi Riau harus menyuplai dari daerah lain (Dinas Tanaman Pangan dan Hortikultura, 2009, h. 122).

Fosfor merupakan salah satu mineral terbanyak dalam tubuh yang jumlahnya hanya dilampaui oleh kalsium. Mineral di golongkan kedalam mineral makro dan mineral mikro. Mineral makro adalah mineral yang di butuhkan tubuh dalam jumlah lebih dari $100 \mathrm{mg}$ sehari (>0,05\% berat badan) sedangkan mineral mikro di butuhkan kurang dari $100 \mathrm{mg}$ sehari $(<0,05 \%$ berat badan). Jumlah mineral mikro dalam tubuh kurang dari $15 \mathrm{mg}$. Sampai saat ini dikenal sebanyak 24 mineral yang di anggap esensial jumlah itu setiap waktu bisa bertambah. Mineral makro terdiri dari Kalsium, Magnesium, Fosfor, Kalium, Natrium dan masih banyak lagi yang lain. Umumnya kelebihan konsumsi mineral akan diekresikan melalui feses kecuali Natium dan Kalium (Departemen Gizi dan Kesehatan Masyarakat, 2008, h. 138).

Jumlah fosfor rata-rata dalam tubuh pria dewasa kurang dari $700 \mathrm{~g}$, sedangkan kalsium 1200 g. Kira-kira $85 \%$ fosfor terdapat dalam tulang sebagai mineral tulang, Kalsium fosfat $\left[\mathrm{Ca}_{3}\left(\mathrm{PO}_{4}\right)_{2}\right]$, dan Hidroksiapatit $\left[\mathrm{Ca}_{10}\left(\mathrm{PO}_{4}\right)_{6}(\mathrm{OH})_{2}\right]$. Sisanya terdapat di dalam sel dan cairan ekstra seluler sebagai ester asam fosfat organik, fosfo protein, fosfo lipida dan ion fosfat anorganik, $\mathrm{H}_{2} \mathrm{PO}_{4}^{-}$dan $\mathrm{HPO}_{4}{ }^{2-}$. Fosfat memegang peranan penting sebagai buffer untuk mencegah perubahan tingkat keasaman cairan tubuh. Ini terjadi karena kemampuan fosfor mengikat tambahan ion hidrogen (Sunita Almatsier, 2001; 244-245).

Walaupun peranan fosfat sangat penting sebagai unsur pokok dari asam nukleat dan membran sel, serta sebagai faktor yang esensial pada seluruh reaksi pembentukan energi di dalam sel dan juga sebagai komponen pembentuk kristal dari tulang rangka, fosfor tidak banyak mendapat perhatian sebagai komponen gizi karena banyak terdapat dalam berbagai jenis makanan yang dikonsumsi.

Fungsi dan metabolisme zat kapur $(\mathrm{Ca})$ dan fosfor (P) sangat erat saling berhubungan, sehingga akan dibicarakan bersama sekaligus. Sebagian besar kedua unsur ini terdapat sebagai garam kalsium fosfat di dalam jaringan keras tubuh, ialah tulang dan gigi geligi, memeberikan sifat keras kepada kedua jenis jaringan tersebut. Dari 1200 gram Ca yang terdapat di dalam tubuh sekitar $90 \%$ terdapat di dalam jaringan keras (tulang dan gigi) sedangkan jaringan lunak hanya mengandung $10 \%$. Dalam hal mineral fosfor, $80 \%$ terdapat di dalam jaringan keras dan $20 \%$ terdapat dalam jaringan lunak, terutama sebagai gugusan asam fosfat. Kadar $\mathrm{P}$ di dalam tubuh sekitar $8 \%$ berat badan.

Fosfor terdapat di dalam jaringan keras lebih rendah dibandingkan dengan kalsium $(\mathrm{Ca})$, tetapi di dalam jaringan lunak bagian fosfor $(\mathrm{P})$ yang ada lebih tinggi di bandingkan dengan kalsium. Banyak mekanisme proses transpor energi dikaitkan pada ikatan fosfat, seperti ATP dan ADP, keratin fosfat dan fosfoenol piruvat. Berbagai metabolit yang memegang fungsi penting mengandung fosfat dan metabolisme zatzat gizi banyak yang dimulai dengan fosforilasi, biasanya dengan peran serta ATP (Yuyum Rumdasih, 2004; 26).

Menurut Sarwono Waspadji mengenai Indeks Glikemiks berbagai makanan Indonesia terlihat kandungan fosfor yang terdapat dalam kacang hijau adalah $340 \mathrm{mg}$ (Sarwono Waspadji 2003; 231). Menurut Sunita Almatsier kandungan fosfor dalam kacang hijau adalah $320 \mathrm{mg}$ (Sunita Almatsier, 2001; 245). Menutut Oe kam Nio kandungan fosfor dalam kacang hijau adalah 320 mg (Oe Kam Nio). Menurut Ali Khomsan kandungan fosfor dalam kacang hijau $326 \mathrm{mg}$ (Ali khomsan 2006; 11-12). Kandungan gizi kacang hijau secara lengkap dapat dilihat pada Tabel 1.

Tabel 1. Kandungan Gizi Kacang Hijau Per $100 \mathrm{~g}$

\begin{tabular}{|l|c|}
\hline \multicolumn{1}{|c|}{ Komponen gizi } & Jumlah \\
\hline Air & 11,7 \\
Energi & 340 \\
\hline
\end{tabular}




\begin{tabular}{|l|c|}
\hline \multicolumn{1}{|c|}{ Komponen gizi } & Jumlah \\
\hline Protein (mg) & 24.1 \\
Lemak (mg) & 1,3 \\
Karbohidrat (mg) & 60,3 \\
Serat (G) & 4,9 \\
Abu (G) & 2,6 \\
Kalsium (mg) & 124 \\
Fosfor (mg) & 326 \\
Fe (mg) & 5,1 \\
Na (mg) & 35 \\
Vitamin. A (IU) & 120 \\
Vitamin B1 (IU) & 0,47 \\
Vitamin B2 (IU) & 0,39 \\
Sumber: Composition Of Foods, Agriculture Handbook \\
No.8, Agricultural Research Servece, US Departement of \\
Agriculture by Bernice K Watt and Annabel L Moril 1975 \\
Washington, DC (Sarwono Waspadji 2003; 231)
\end{tabular}

Pada umumnya kacang hijau banyak dikonsumsi oleh orang dewasa maupun anakanak sampai balita. Kebanyakan orang mengkonsumsi kacang hijau hanya sesekali dan sebatas mengkonsumsi saja tanpa memperhatikan kandungan gizi yang terdapat dalam kacang hijau, padahal dari hasil penelitian kacang hijau banyak mengandung fosfor yang sangat bermanfaat untuk memperkuat kerangka tulang dan gigi. Angka kecukupan fosfor rata-rata sehari untuk Indonesia ditetapkan untuk bayi 200-250 mg, untuk anak-anak 250-400 mg, untuk remaja dan dewasa 400-500 mg, ibu hamil dan menyusui 200-300 mg.

Fungsi fosfor dalam ketersediaannya di dalam tubuh yaitu:

1. Mempengaruhi semua proses perombakan dan pembentukan zat

2. Membentuk fosfatida, yaitu bagian penting dari plasma

3. Pembelahan inti sel dan memindahkan sifat-sifat turunan

4. Membentuk matriks tulang (bersamasama dengan Kalsium)

5. Membantu proses pengerutan otot (Marsetyo, 2008; 91-92 ).

Fosfor merupakan bagian dari asam nukleat DNA dan RNA yang terdapat dalam tiap inti sel dan sito plasma tiap sel hidup. Sebagai fosfolipid, fosfor merupakan komponen struktural dinding sel (Sunita Almatsier, 2001; 243). Fosfor terdapat di dalam jaringan keras dalam jumlah lebih rendah dibandingkan dengan $\mathrm{Ca}$, tetapi di dalam jaringan lunak bagian $\mathrm{P}$ yang ada lebih tinggi dibandingkan dengan $\mathrm{Ca}$. Banyak mekanisme proses transpor energi dikaitkan pada ikatan fosfat, seperti ATP dan ADP, keratin fosfat dan fosfoenol piruvat. Berbagai metabolit yang memegang fungsi penting mengandung fosfat dan metabolisme zat-zat gizi banyak yang dimulai dengan fosforilasi, biasanya dengan peran serta ATP (Yuyum Rumdasih, 2004; 26 ).

Dari uraian di atas jelas terlihat bahwa didalam kacang hijau mengandung fosfor antara 320-340 mg yang relative tinggi. Dan karena fosfor memegang peranan penting dalam tubuh manusia maka penulis tertarik untuk melakukan penelitian guna untuk membuktikan apakah benar didalam kacang hijau terdapat kandungan fosfor yang relative tinggi dengan judul "Analisa Kadar Fosfor Dalam Kacang Hijau Dengan Metode Spektrofotometri UV-Vis Di Pasar Pekanbaru".

\section{METODOLOGI PENELITIAN}

1. Pembuatan Pereaksi molibdat vanadat Larutan ini dibuat dengan melarutkan 20 g amonium malibdat kedalam $200 \mathrm{~mL}$ aquadest panas kemudian dinginkan. Melarutkan 1,0 $\mathrm{g}$ amonium metavanadat kedalam $125 \mathrm{~mL}$ aquadest panas, dan mendinginkannya kemudian menambahkan $160 \mathrm{~mL} \mathrm{HCl}$, dan memasukkannya kedalam labu ukur 1 liter. Pertama memasukkan larutan vanadat kemudian menambahkan larutan molibdat sambil diaduk dan terakhir menambahkan aquadest sampai tanda batas.

2. Pembuatan Larutan Standart Fosfor Larutan baku induk, menimbang \pm $1,5354 \quad \mathrm{~g} \quad \mathrm{KH}_{2} \mathrm{PO}_{4} \quad(P a) \quad$ dan mengeringkannya di dalam oven selama 2 jam pada suhu $105{ }^{\circ} \mathrm{C}$ kemudian memindahkannya secara kuantitatif kedalam labu ukur $50 \mathrm{~mL}$, menambahkan aquadest sebagai pelarut sampai tanda batas kemudian dinginkan dalam lemari pendingin. 
3. Preparasi sample (Kacang Hijau)

Cara kerja:

Menimbang dengan seksama 10,0 g sampel kedalam cawan porselen dengan mengarangkan diatas api bunsen, memasukkan sampel kedalam oven selama 3 jam untuk mengurangi kadar air, memasukkan sampel kedalam tanur pengabuan pada suhu $600^{\circ} \mathrm{C}$ sampai bebas karbon (3-4 jam) dan dinginkan, memasukkan abu sampel kedalam beker glas $250 \mathrm{~mL}$, menambahkan $40 \mathrm{~mL} \mathrm{HCl}$ (1:3) dan beberapa tetes $\mathrm{HNO}_{3}$, memanaskan dalam water batch, dan dinginkan, memindahkan secara kuantitatif kedalam labu ukur $10 \mathrm{~mL}$, menambahkan aquadest sampai tanda batas.

\section{HASIL DAN PEMBAHASAN}

\section{Penentuan Panjang Gelombang Optimum}

Sebelum dilakukan analisa kadar dengan menggunakan metode spektrofometri UV-VIS terlebih dahulu dilakukan penentuan panjang gelombang optimum, meskipun panjang gelombang tersebut sudah diketahui dalam literatur. Hal ini dikarenakan panjang gelombang suatu senyawa dapat berbeda bila ditentukan pada kondisi dan alat yang berbeda. Penentuan panjang gelombang pada penelitian ini dilakukan pada larutan 0,3\% dengan range 380-450 dengan kenaikan $5 \mathrm{~nm}$. dan berikut data panjang gelombang dan absorbansi masing-masing.

Tabel 2. Hasil pencarian panjang gelombang (ג) Optimum.

\begin{tabular}{|c|c|}
\hline Panjang gelombang $(\boldsymbol{\lambda})$ & Absorban (A) \\
\hline 380 & 0,2986 \\
385 & 0,3895 \\
390 & 0,4565 \\
395 & 0,6042 \\
$\mathbf{4 0 0}$ & $\mathbf{0 , 6 9 4 1}$ \\
405 & 0,5738 \\
410 & 0,5183 \\
415 & 0,4862 \\
420 & 0,4615 \\
425 & 0,4267 \\
430 & 0,3941 \\
\hline
\end{tabular}

\begin{tabular}{|l|l|}
\hline 435 & 0,3723 \\
440 & 0,3509 \\
445 & 0,3128 \\
450 & 0,2969 \\
\hline
\end{tabular}

Berikut adalah kurva panjang gelombang optimum antara absorban dengan panjang gelombang.

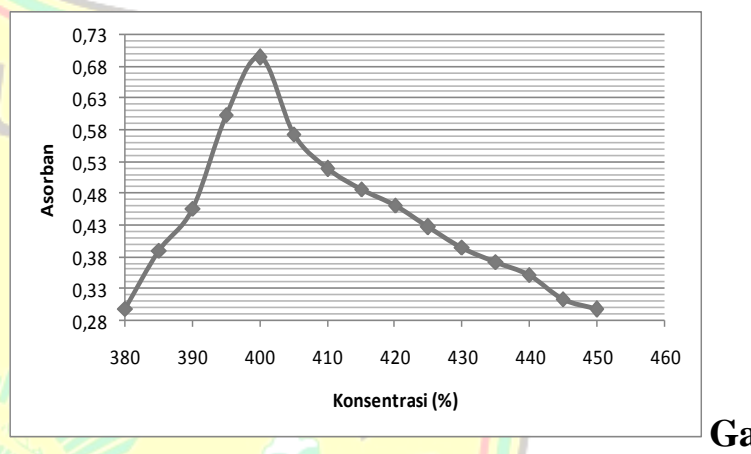

mbar 1. Hasil Penentuan Panjang Gelombang Optimum

\section{Pembuatan kurva kalibrasi standar}

Dibuat larutan seri satandar dari larutan induk $0,7 \%$. Dipipet larutan induk sebanyak 1.4; $2.8 ; 4.2 ; 5.7$; dan $7.1 \mathrm{~mL}$ sehingga larutan tersebut mempunyai konsentrasi, $0.1 ; 0.2 ; 0.3$; 0.4 ; dan $0.5 \%$. lalu dimasukkan dalam labu 10 $\mathrm{mL}$ tambahkan pereaksi molibdat-vanadat $2 \mathrm{~mL}$ kemudian diencerkan sampai tanda batas, absorban diukur pada panjang gelombang 400 nm.

Pada penelitian ini didapatkan data absorban pada setiap konsentrasi dari larutan standar sebagai berikut:

Tabel 3. Kurva Kalibrasi

\begin{tabular}{|l|l|}
\hline Konsentrasi (\%) & Absorbansi (A) \\
\hline 0,1 & 0,2287 \\
\hline 0,2 & 0,3795 \\
\hline 0,3 & 0,4540 \\
\hline 0,4 & 0,6477 \\
\hline 0,5 & 0,7293 \\
\hline
\end{tabular}




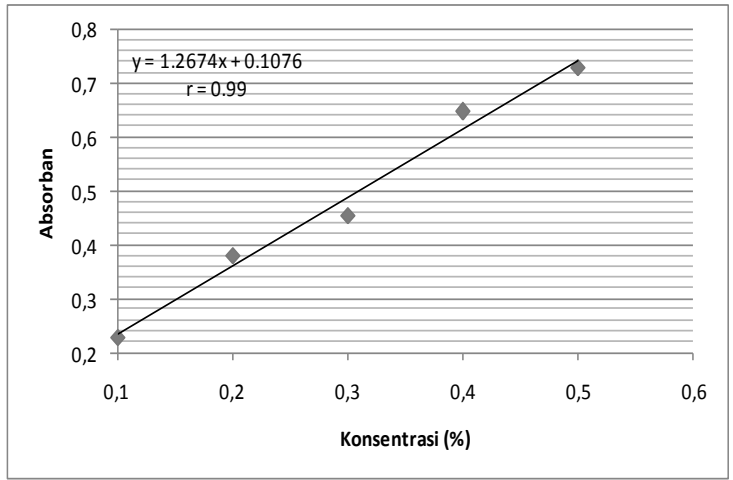

Gambar 2. Kurva Kalibrasi

Pada uji linieritas penentuan regresi dari standard kurva kalibrasi, diperoleh koefisien korelasi dan diketahui kondisi alat spektropothometer yang digunakan sudah mewakili jumlah sampel. Hasil dari kurva kalibrasi standar diperoleh nilai korelasi $r$ sebesar 0,99 yang menunjukkan ada hubungan linier yang erat antara konsentrasi yang diukur dengan absorban yang dihasilkan. Setelah melalui perhitungan regresi linier kurva standar, $\mathrm{Y}=\mathrm{a}+$ $\mathrm{bX}$, maka didapatlah $\mathrm{y}=0,1076+1,2674 \mathrm{x}$. Sehingga dapat menghitung konsentrasi tiap sampel kacang hijau.

Pada penelitian ini telah diperoleh hasil pada larutan standar / dimana nilai absorbansi meningkat seiring dengan peningkatan nilai konsentrasi, dapat dilihat dimana pada konsentrasi $0,1 \%$ diperoleh nilai absorbansi sebesar 0,2287 dan pada konsentrasi 0,5\% diperoleh absorbansi 0,7293. Sedangkan pada pengujian absorbansi konsentrasi sampel, nilai absorbansi pun berbanding lurus dengan nilai konsentrasi fosfor pada sampel.

\section{Larutan standar fosfor}

Dalam menggunakan spektrofotometer, untuk menghindari kesalahan pengukuran, sebaiknya bekerja pada larutan dengan konsentrasi dimana transmitannya antara 20 $80 \%$ atau absorbansinya antara $0,2-0,8$. Dari kondisi ini diharapkan kesalahan dalam pembacaan $\mathrm{T}$ adalah 0,005 atau $0,5 \%$ (kesalahan fotometrik) sebagaimana gambar IV.4 Apabila absorban berada diatas 0,8 maka dilakukan pengenceran pada larutan standar, dan apabila absorban berada dibawah 0,2 maka dilakukan internal standart. Dengan menggunakan absorban antara 0,2 - 0,8 maka dapat memperkecil kesalahan dalam penelitian.

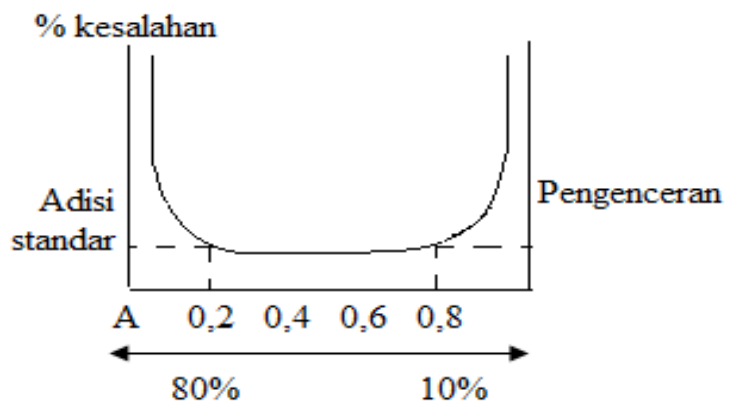

\section{Gambar 3. Perlakuan Larutan Standar/ Sampel Terhadap Absorban Pada Spektrofotometer.}

Larutan baku yang dipergunakan untuk membandingkan kandungan fosfor dalam sampel adalah larutan baku $\mathrm{KH}_{2} \mathrm{PO}_{4}$, sebelum larutan dibuat, $\mathrm{KH}_{2} \mathrm{PO}_{4}$ dikeringkan terlebih dahulu didalam oven selama 3 jam pada suhu $105{ }^{\circ} \mathrm{C}$, hal ini dilakukan untuk menghilangkan kadar air $\left(\mathrm{H}_{2} \mathrm{O}\right)$ yang terkandung dalam bahan untuk menghindari terjadinya reaksi kompleksometri yang lain dari pereaksi molibdat-vanadat dengan air tersebut.

Setelah bahan $\mathrm{KH}_{2} \mathrm{PO}_{4}$ dikeringkan dalam oven, lalu dibuat larutan standar (larutan baku induk) sebagai standar atau acuan perhitungan fosfor pada sampel. Pertama-tama dibuat larutan induk $0,7 \%$ dalam labu $50 \mathrm{~mL}$ kemudian dibuat larutan seri standar dengan konsentrsi $0.1,0.2$, $0.3,0.4$, dan $0.5 \%$. Setelah itu terbentuklah larutan standar.

\section{Penentuan Kadar Fosfor Dalam Sampel Kacang Hijau (Phaseolus Radiatus. L.)}

Pembuatan larutan uji, dimulai dengan menimbang sampel kacang hijau sebanyak 10 gram, lalu di masukkan dalam oven dengan suhu $105{ }^{\circ} \mathrm{C}$ selama 3-4 jam. Setelah sampel selesai di oven, kemudian dilakukan proses pengabuan yaitu dengan memasukkan sampel kedalam tanur untuk proses pengabuan pada suhu $600{ }^{\circ} \mathrm{C}$ selama 4 jam sampai bebas karbon dan dinginkan. Pengabuan yang sempurna biasanya ditandai dengan sampel yang telah berubah menjadi abu berwarna putih setelah sampel jadi abu, 
kemudian dipindahkan secara kuantitatif kedalam beaker glass dan ditambahkan dengan $40 \mathrm{~mL} \mathrm{HCl}$ (1:3) dan beberapa tetes $\mathrm{HNO}_{3}$ 65\% dan dipanaskan selama 30 menit dalam water bath pada suhu $70{ }^{\circ} \mathrm{C}$, hal ini dilakukan bertujuan untuk proses dekstruksi sampel.

Setelah sampel selesai didekstruksi, maka selanjutnya dimasukkan secara kuantitatif kedalam labu $10 \mathrm{~mL}$ dan ditambah pereaksi molibdat-vanadat lalu ditambahkan aquadest sampai tanda batas dan didiamkan selama 10 menit untuk pembentukan warna.

Kemudian diukur absorbansinya dengan spektrofotometer UV-Vis pada panjang gelombang $400 \mathrm{~nm}$. Nilai absorbansi yang telah diperoleh nantinya akan dihubungkan dengan metode regresi linear, terhadap nilai pada larutan standar pada tiap konsentrasi untuk mendapatkan nilai konsentrasi pada sampel.

Larutan baku yang dipergunakan untuk membandingkan kandungan fosfor dalam sampel adalah larutan baku $\mathrm{KH}_{2} \mathrm{PO}_{4}$, sebelum larutan dibuat, $\mathrm{KH}_{2} \mathrm{PO}_{4}$ dikeringkan terlebih dahulu didalam oven selama 3 jam pada suhu $105^{\circ} \mathrm{C}$, hal ini dilakukan untuk menghilangkan kadar air $\left(\mathrm{H}_{2} \mathrm{O}\right)$ yang terkandung dalam bahan untuk menghindari terjadinya reaksi kompleksometri yang lain dari pereaksi molibdat-vanadat dengan air tersebut.

\section{Tujuan Analisa kadar fosfor}

Fosfor merupakan mineral kedua terbanyak di dalam tubuh, yaitu $1 \%$ dari berat badan. Kurang lebih $85 \%$ fosfor di dalam tubuh terdapat sebagai garam kalsium fosfat di dalam tulang dan gigi yang tidak dapat larut. Fosfor di dalam tulang berada dalam perbandingan 1:2 dengan kalsium. Fosfor selebihnya terdapat di dalam semua sel tubuh, separuhnya di dalam otot dan di dalam cairan ekstraselular. Sebagai fosfolipid, fosfor merupakan komponen struktural dinding sel. Sebagai fosfat organik, fosfor memegang peranan penting dalam reaksi yang berkaitan dengan penyimpanan atau pelepasan energi dalam bentuk Adenin Trifosfat

Pada umumnya bahan makanan yang mengandung banyak kalsium merupakan juga sumber fosfor, seperti susu, keju, daging, ikan, telur, serelia. Akan tetapi fosfor dalam serelia pada umumnya terdapat dalam bentuk asam fosfat yang dapat mengikat kalsium hingga terbentuk komponen yang tidak dapat dicerna dan diserap (Katarin Sitompul, 2009; 4 )

Maka tujuan analisa kadar fosfor dalam kacang hijau adalah untuk mengetahui kandungan fosfor dalam kacang hijau di pasar Pekanbaru.

\section{Tabel 4. Hasil Absorbansi Sampel}

\begin{tabular}{|c|c|c|c|}
\hline \multirow{2}{*}{ Sampel } & \multicolumn{3}{|c|}{ Absorbansi } \\
\cline { 2 - 4 } & $\mathbf{1}$ & $\mathbf{2}$ & $\mathbf{3}$ \\
\hline 1 & 0,3041 & 0,3320 & 0,3127 \\
\hline 2 & 0,3487 & 0,3289 & 0,3149 \\
\hline 3 & 0,3454 & 0,3263 & 0,3329 \\
\hline
\end{tabular}

\section{Analisis kuantitatif fosfor}

Analisis dilakukan secara spektrofotometri sinar tampak. Prinsipnya yaitu sampel diperlakukan dengan asam nitrat untuk mengubah semua metafosfat dan pirofosfat menjadi ortofosfat yang ada dalam sampel akan bereakasi dengan pereaksi-pereaksi tersebut dan membentuk kompleks asam vanadi-molibdat yang berwarna kuning. Intensitas warna dari senyawa kompleks tersebut dapat diukur dengan spektrofotometer panjang gelombang $400 \mathrm{~nm}$ dan dibandingkan dengan standar fosfor yang telah diketahui konsentrasinya.

Tabel 5. Perolehan Kadar Fosfor Dalam Sampel

\begin{tabular}{|c|c|c|c|c|c|}
\hline \multirow{2}{*}{ Sampel } & \multirow{2}{*}{ Kadar } & \multicolumn{3}{|c|}{ Ulangan } & $\begin{array}{c}\text { Kadar } \\
\text { Fosfor } \\
\text { Rata-rata } \\
\text { (mg/10g) }\end{array}$ \\
\hline & & $\mathbf{1}$ & $\mathbf{2}$ & $\mathbf{3}$ & \\
\hline 1 & Fosfor & 77,5 & 88,5 & 80,9 & 82,3 \\
\hline 2 & Fosfor & 95,1 & 87,3 & 81,75 & 88,05 \\
\hline 3 & Fosfor & 93.8 & 86,25 & 88.85 & 89.63 \\
\hline
\end{tabular}

Keterangan:

1. Sampel varietas Finna dari Pasar Arengka $(=$ Kadar terendah)

2. Sampel varietas Sriti dari Pasar Panam

3. Sampel varietas Mawarjaya dari Pasar Giant ( Kadar tertinggi).

Dari hasil penenelitian ini didapat sampel kacang hijau dari pasar Giant mengandung kadar fosfor tertinggi yaitu sebesar $89,63 \mathrm{mg} / 10 \mathrm{gr}$ 
kacang hijau, sedangkan kacang hijau dari pasar arengka sebesar $82,3 \mathrm{mg} / 10 \mathrm{gr}$.

\section{KESIMPULAN}

Dari hasil analisis sampel kacang hijau yang didapat dari pasar arengka, pasar panam, pasar giant terdapat kadar fosfor rata-rata antara 82,3$89,63 \mathrm{mg} / 10 \mathrm{~g}$. Dan kadar fosfor tertinggi terdapat dalam sampel yang berasal dari pasar Giant yaitu varietas Mawarjaya, sedangkan yang terendah dari pasar Arengka yaitu varietas Finna. Setelah melakukan penelitian analisa kadar fosfor pada kacang hijau dapat diketahui nilai absorbansi dan konsentrasi yang terkandung dalam bahan pangan tersebut serta dapat mengetahui cara pengujiannya. Nilai absroban selalu berbanding lurus dengan nilai konsentrasi.

Disarankan kepada peneliti selanjutnya agar dapat menganalisa kadar fosfor dalam kacangkacangan yang lain menggunakan metode spektrofotometri. Selanjutnya kepada masyarakat pada umumnya dan kepada ibu-ibu hamil pada umumnya agar mengkonsumsi kacang hijau dalam jumlah banyak karena didalam kacang hijau terdapat kandungan fosfor yang tinggi yang sangat dibutuhkan/oleh tubuh untuk awal pembentukan tulang dan gigi.

\section{DAFTAR PUSTAKA}

Ali Khomsan, Solusi Makanan Sehat, PT Raja Grafindo Persada, Jakarta, 2006, h. 11-12.
Atman, Teknologi Budidaya Kacang Hijau Dilahan Sawah, Peneliti balai pengkajian teknologi pertanian, Sumatra Barat, 2007, h. 1.

Departemen Gizi dan Kesehatan Masyarakat, Fakultas Kesehatan Masyarakat, Gizi dan kesehatan masyarakat, PT Raja Grafindo Persada UI, Jakarta, 2008, h. 138.

Dinas Tanaman Pangan dan Hortikultura, Buku Statistik Pertanian Tanaman Pangan Dan Hortikultura, Pekanbaru, 2009, h. 122.

Katarin Sitompul, Penetapan Kadar Fosfor Dalam Buah Apel Secara Spektrofotometri Sinar Tampak, (Sumatera Utara, 2009) h. 4.

Marsetyo, Kartasapoetra.G, Ilmu gizi, Rineka Cipta, Jakarta, 2008, h. 91-92.

Oe Kam Nio, Daftar Analisis Bahan Makanan, Balai Penerbit Fakultas Kedokteran UI, Jakarta, 1992, h. 14.

Sarwono Waspadji, Indeks Glikemik Berbagai makanan Indonesia Hasil Penelitian, Balai Penerbit Fakultas Kedokteran UI, Jakarta, 2003, h. 231. 